\title{
Alberto Nepomuceno: vínculos modernistas no Trio em \\ Fá sustenido menor (1916)
}

\author{
Luiz Guilherme Duro Goldberg' \\ (Universidade Federal de Pelotas)
}

\section{Resumo:}

Alberto Nepomuceno tem sido descrito, pela tradição historiográfica brasileira, invariavelmente, pelos seus vínculos com o nacionalismo musical. No entanto, como interpretar as considerações a respeito de seu modernismo musical? Uma das obras pilares para esse entendimento é o seu Trio em fá sustenido menor, para violino, violoncelo e piano, composto em 1916. Tendo as críticas de sua estreia e da Audición de Obras de Compositores Brasileños, ocorrido em Buenos Aires, em 1919, como substrato, procedeu-se a análise dessa obra para, a partir daí, compreender os pareceres nelas veiculados, bem como diagnosticar os seus vínculos com o modernismo musical.

Palavras-chave: Alberto Nepomuceno; modernismo musical; Trio; análise musical.

\footnotetext{
${ }^{1}$ Atualmente é professor adjunto no Conservatório de Música da Universidade Federal de Pelotas. Tem experiência na área de Artes, com ênfase em Música Brasileira na Primeira República e Análise Grafotécnica atuando principalmente nos seguintes temas: modernismo musical na Primeira República, música de Alberto Nepomuceno e edição de partituras.
} 
No transcorrer da vida musical de Alberto Nepomuceno, o caminho iniciado em sua Variations sur un Theme Original op. 29, de 1902, mostrou-se como um portal para novas expressões, cabendo ao crítico Luiz de Castro um dos primeiros diagnósticos sobre essas transformações, cujas ousadias harmônicas do compositor, observadas em seu Trio para piano, violino e violoncelo (1916), o tinham convertido definitivamente em um compositor completamente moderno.

Referindo-se ao seu concerto de estreia, em 31 de agosto de 1916, assim Luiz de Castro prossegue:

A quem tem acompanhado de perto a carreira artistica de Nepomuceno, a primeira impressão que logo se sente ao ouvir o Trio é da completa transformação operada no systema harmonico adoptado pelo autor da 'Symphonia em sol menor'. Acompanhando, como todo artista digno desse nome, a evolução musical, elle se tornou um compositor completamente moderno, que não recua deante das mais ousadas combinações harmonicas, sem que, entretanto, haja nellas cousa alguma que offenda os ouvidos; e é assim que, no seu Trio, ha effeitos novos, bizarros, curiosos, interessantes. Essa transformação, a que me refiro, começou a se manifestar na sua obra para piano, 'Thema e Variações', ${ }^{2}[\ldots]$. Depois, ella se accentuou na comedia musical 'O Garatuja', [...], e escripta em estylo completamente differente do 'Abul'.

A segunda impressão deixada pelo Trio é da sua completa unidade. Toda a obra se basea no thema da introducção, do qual se originam os themas dos quatro tempos do Trio. No seu desenvolvimento, nas suas combinações harmonicas, ha uma riqueza extraordinaria, a par de uma suavidade pouco vulgar. Ao primeiro 'allegro', em que se notam contrastes impressionantes, effeitos novos, precisão, succede um 'andante' de profundo sentimento, pagina de rara elevação, que commove e traz a fielmente todo o sentimentalismo da alma cearense. Mas essa alma é feita de contrastes violentos. Tão depressa se absorve em doce melancolia, quanto se entrega logo em seguida ás travessuras infantis. São estas travessuras que surgem no 'Scherzo', que como seu nome indica, é um gracejo. Dir-se-ião creanças a brincar extravagantemente, desordenadamente; mas eis que a brincadeira é um instante interrompida; o motivo central traduz como que repentina contrariedade, que ennuvia o semblante das creanças. É um instante, e as travessuras recomeçam, e quando ellas acabam, o publico pede 'bis'. O Final

\footnotetext{
2 Embora o nome Thema e Variações seja o título de seu op. 28, creio que a obra a qual Luiz de Castro se refere é a Variations sur un Théme original op. 29. Tal avaliação se deve ao fato de a obra op. 28 ser tributária a Brahms, enquanto a sua op. 29 mostra-se mais experimental e inovadora. Reforça tal conclusão a confusão apresentada no catálogo da Exposição Comemorativa do Centenário do Nascimento de Alberto Nepomuceno, onde na vitrine $\mathrm{n}^{\circ} \mathrm{X}$, item 130, apresenta a partitura do "Tema e Variações op. 28" com a observação "manuscrito original para piano com o título de Variações sobre um tema original".
} 
inicia-se com o thema do começo, a que se segue logo um allegro de uma alegria communicativa. É a vontade de viver, é a manifestação radiosa da alma por tudo quanto ha de bom na vida, pelos prazeres inegualaveis que a arte sadia e forte proporciona. E a obra termina assim em um raio de luz fulgurante, que provoca o enthusiasmo do auditorio.O Trio em fá sustenido menor de Alberto Nepomuceno é uma obra prima. (A Noite, 1/9/1916)

Ainda de acordo com Luiz de Castro, na mesma coluna, entre as figuras ilustres que presenciaram a sua estreia, encontravam-se os compositores e maestros franceses Xavier Leroux e Andre Messager, ${ }^{3}$ cujo entusiasmo o fez dirigirse a Nepomuceno exclamando "Você estreou por um golpe de mestre!", ${ }^{4}$ além de manifestar que faria executar o Trio em Paris pela Société Nationale de Musique de Chambre.

Entretanto, a manifestação de Messager não se restringiria a esta declaração. Em 16 de setembro de 1916, faz publicar no Jornal do Commercio

Na sala de concertos do Jornal do Commercio nos convocamos ontem de manhã, Xavier Leroux e eu, para escutar dois trios de dois mestres brasileiros. Alguns raros privilégios deslizam discretamente, [...] admiradores dos dois compositores, e lá passamos duas horas deliciosas consagradas à arte mais sincera e mais pura. É primeiro o Trio de Alberto Nepomuceno; e, desde os primeiros compassos do tema que serve de base aos quatro movimentos da obra, sentimo-nos tomados, movidos por este pensamento sério, nobre e profundo. Esta é, parece, a primeira obra de música de câmara composta por Nepomuceno, mas se pode, sem hesitar, aplicar-lhe os versos de Corneille:

'Seus semelhantes duplamente não se fazem conhecer

E para suas tentativas querem os lances de mestre!'

Patético no primeiro movimento, comovente no andante, cheio de verve e originalidade rítmica no Scherzo, potente e voluntário no final que resume e comenta a obra inteira, tal é este Trio que coloca desde a primeira ação seu compositor no rol dos melhores da música moderna. (Jornal do Commercio, 16/9/1916, tradução nossa)

\footnotetext{
${ }^{3}$ André Messager (1853-1929) foi membro do comitê de direção da Société Nationale de Musique, ao lado de Alfred Bruneau. Claude Debussy. Paul Dukas, Henri Duparc e Vincent d'Indy, durante a presidência de Gabriel Fauré, em 1914 (Duchesneau, 1997, p. 47). Dirigiu a orquestra da Opéra-Comique (1898-1903), do Covent Garden, em Londres, (1901-1907) e da Opéra de Paris (1907-1913). Regeu a estreia de Pelléas et Mélisande de Debussy, sendo a ele dedicada. (Anglés, H., Pena, J. Diccionario de la Música Labor, 1954. v. 2, p. 1522).

4 “Vous avez débuté par un coup de maître!” (A Noite, 1/9/1916, tradução nossa).
} 
No ano seguinte, Darius Milhaud compartilhava da mesma opinião e ansiava pela sua publicação para levá-lo a Europa, conforme atesta sua carta datada de 23 de maio de 1917 e publicada no Jornal de Commercio no dia 28 de maio.

Tenho a dizer-vos toda a alegria que provei ontem ouvindo vosso bonito trio. Mr. Henrique Oswald tinha-me avisado do ensaio de seu trio e do vosso no Instituto e fiquei muito feliz de ouvir as duas obras nas quais se desenham claramente os diferentes temperamentos dos dois maiores compositores do Brasil.

Eu reencontrei, na audição de ontem, todas as qualidades de vigor, de grandeza, de profundidade de sentimento que havia sentido em vosso trio quando amavelmente o havia mostrado ao piano.

Espero que você o publique logo para que eu possa levá-lo à Europa e o submeter a meus amigos em Paris, logo que eu retorne. (Jornal do Commercio, 28/5/1917, tradução nossa)

Entretanto, não se conclua daí a unanimidade nas considerações a respeito deste Trio. Tal se depreende da Audición de Obras de Compositores Brasileños ocorrida em Buenos Aires, em 10/12/1919, promovido pela Asociación Wagneriana de Buenos Aires. ${ }^{5}$

Segundo o articulista da Revista de la Asociación Wagneriana de Buenos Aires,

O Trio para piano, violino e violoncelo, de Alberto Nepomuceno, com o qual iniciou a audição, é uma obra de perfeita claridade, com ideias melódicas belamente desenvolvidas e ponderada ciência musical, que deixa sempre livre o vôo da inspiração. Acusa, talvez, menos que as demais do programa a influência francesa, sem que isto signifique que se aparte dela em absoluto. (Revista de la Asociación Wagneriana de Buenos Aires, 1919, p. 11-12. tradução nossa).

No mesmo viés, ressaltando aspectos positivos, encontram-se considerações sobre a sua forma e concepção clássicas (La Argentina,

\footnotetext{
${ }^{5}$ Neste concerto, além do Trio em Fá sustenido menor de Nepomuceno, figuraram no programa: I/ Neige, para piano, Elegie, para violoncelo e piano e Romance, para violino e piano, de Henrique Oswald; Les Cloches e Les brebis qui rentrent, para piano de Alfredo Oswald; Quarteto op. 56, para dois violinos, viola e violoncelo, de Villa-Lobos. A obra de Villa-Lobos pode ser identificada como sendo o Quarteto de Cordas $n^{\circ} 2$ (1915), em virtude de seus movimentos.
} 
11/12/1919), cujo tema inicial de caráter severo e arcaico (La Prensa, 11/12/1919), é um recitativo gregoriano de extraordinária nobreza (La Nación, 12/12/1919), além do seu notável sentido de proporção e perfeito equilíbrio entre as sonoridades dos instrumentos (La Época, 11/12/1919).

Em contraponto, alguns jornais ressaltam certa falta de unidade (Tribuna Española, 11/12/1919), seu escasso interesse devido seu caráter confuso e trivial nos últimos movimentos (La Vanguardia, 12/12/1919), ou mesmo "uma monótona vulgaridade, que nem sequer tem a atenuante de um tema 'folclórico'; é simples música italiana, de cinqüenta anos, e com marcadas tendências líricas."6 (La Unión, 11/12/1919)

Embora este conjunto de críticas possa ser interpretado segundo vários vieses, importa neste momento decifrá-lo de acordo com os aspectos técnicos que o norteou. Desta maneira, talvez se conclua as razões geradoras das avaliações negativas acima referidas. No entanto, é interessante observar que enquanto as críticas de Luiz de Castro ou Messager se referiam ao modernismo deste Trio, os escritos argentinos detectaram alguma influência francesa.

Como denominador comum, encontra-se o fato de seu tema inicial ser

58 percebido como básico para toda a obra, o que remete as avaliações a sua estrutura de sonata cíclica. Possivelmente isto tenha contribuído para que o Trio fosse considerado de concepções clássicas, explicitado em seu sentido de proporção, e mais afastado da influência francesa, embora seja um exagero considerá-lo "música italiana” ou trivial.

Deve-se lembrar que Alberto Nepomuceno estudara na Schola Cantorum, pilar educacional da Société Nationale de Musique, que privilegiava as grandes formas tradicionais (Duchesneau, 1997, p. 155), entre elas a sonata cíclica. Segundo Vincent d'Indy, diretor da Schola e sucessor de César Franck na presidência da Société Nationale, incluindo uma franca propaganda nacionalista em seu Cours de

\footnotetext{
6 "La sesión daba comienzo con un trío en fa sostenido menor de Alberto Nepomuceno, que consta de cuatro tiempos. En ninguno se nos dice nada nuevo: transcurren en una monótona vulgaridad, que ni siquiera tiene la atenuante de un tema 'folklórico'; es simples música italiana, de hace cincuenta años, y con marcadas tendencias líricas." (La Unión. 11/12/1919)
} 
Composition Musicale (1909), coube à França levar essa forma cíclica à perfeição pelo trabalho de Franck, a quem considerava herdeiro direto de Beethoven. ${ }^{7}$

Entretanto, se a princípio a Société Nationale era considerada por seu viés moderno, em finais da primeira década do século XX isto não mais ocorria. Daí a cisão responsável pelo estabelecimento da Société Musicale Indépendante que pregava a liberdade estrutural, em oposição às formas preconizadas pela Schola.

Assim, é sintomático que enquanto a Société Musicale Indépendante já havia realizado um Festival Arnold Schoenberg em 15 de dezembro de 1927 (Duchesneau, 1997, p. 322), este compositor só tenha sido incluído nos programas de concertos da Société Nationale a partir de 1938 (Duchesneau, p. 48), apesar de isto também refletir um ordenamento estatutário sobre as questões nacionalistas, responsáveis pela própria criação desta Société.

Por outro lado, levando-se em consideração somente compositores franceses, observa-se que enquanto alguns tinham livre trânsito entre ambas as sociedades, como Claude Debussy, ${ }^{8}$ membro do Comitê Executivo da Nationale em 1893, ou Gabriel Fauré (1845-1924), que foi presidente tanto da Indépendante, em 1910, quanto da Nationale, em 1917, outros eram exclusivos, como André Messager, vinculado à Nationale e membro da sua diretoria durante a presidência de Fauré, ou Maurice Ravel (1875-1937), fundador da Indépendante em 1910, ou Darius Milhaud, "acolhido de braços abertos" por esta sociedade (Duchesneau, 1997, p. 66).

Desta maneira, e retornando-se ao Trio de Nepomuceno, pode-se concluir que as considerações efetuadas por Messager ${ }^{9}$ e Milhaud representem os posicionamentos estéticos da Société Nationale de Musique e da Société Musicale Indépendante, respectivamente. Daí o fato de este Trio, de "notável

\footnotetext{
${ }^{7}$ Segundo Vincent d'Indy, em seu Cours de Composition Musicale, "C'est à la France qu'il devait appartenir de poursuivre et de réaliser la transformation de la Sonate, clairement indiquée par Beethoven" (d'Indy, 1909, p. 421), cujos elementos cíclicos foram "organisés consciemment et dans toute leur plénitude par César Franck." (d'Indy, p. 375).

${ }^{8}$ Sobre a relação entre Debussy, d'Indy e a Société Nationale ver Davidian, Teresa (1991).

${ }^{9}$ Importante observar que a intenção de Messager, de executar a obra em concertos da Société Nationale não se concretizou, já que até 1917 não havia sido publicada (como se lê na declaração de Milhaud) e a partir de outubro desse ano tal Société fechara-se novamente para músicos estrangeiros, conforme alteração estatutária (Duchesneau, 1997. p. 47-48). Quanto a alguma programação em concertos da Société Musicale Indépendante, nenhum registro foi encontrado.
} 
sentido de proporção" em sua estruturação cíclica, ser considerado como obra moderna por Messager enquanto que Milhaud restringe-se ao seu vigor e profundidade de sentimento.

No entanto, embora a forma cíclica possa credenciar esta obra a algum vínculo com o modernismo musical, certamente este não foi o fator determinante. Mais fundamental se torna a observação de duas características do tema cíclico, apresentado no início do Trio (Exemplo 1).

Exemplo 1 Trio em Fáł menor: Frase inicial, geradora dos motivos cíclicos.

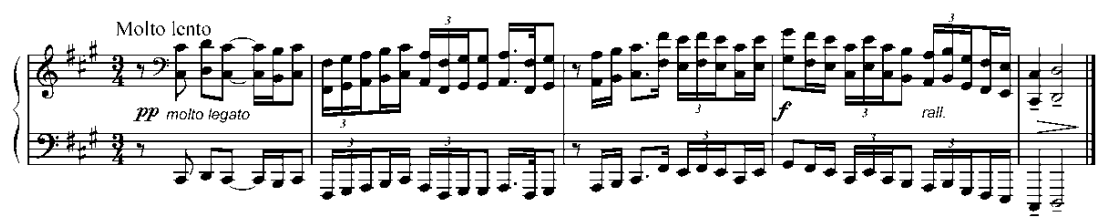

A primeira delas, diz respeito ao seu caráter severo e arcaico, como um "recitativo gregoriano", reflexo do modalismo empregado que condiciona as suas estruturas e progressões harmônicas, particularidade esta que reverbera um dos vieses do modernismo musical.

Outra característica brota da especulação de uma provável referência a obras de Debussy. Se por um lado, parece haver uma citação da ideia inicial de Les Chansons de Bilitis (1900-1901), Exemplo 2, por outro, conforme Corrêa do Lago, em seu início, este Trio assemelha-se, pela alternância entre as texturas monódica em oitavas e cordal modal em registros semelhantes, à Hommage a Rameau, n. 2 da primeira série das Images (1905).

Exemplo 2 Paralelo entre fragmento melódico do Tema do Trio de Nepomuceno com o início de Pour invoquer Pan. Dieu du vent d'été de Six Epigraphes Antigues de C. Debussy.

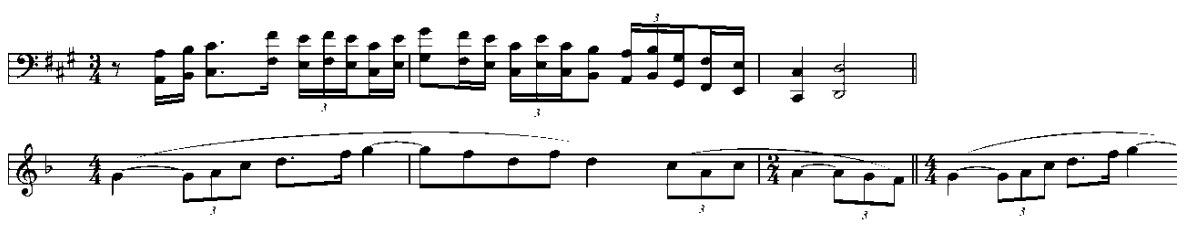


Embora em seu título esteja indicado que se trata de uma obra tonal, tendo as relações de mediantes cromáticas e de quintas relevância estrutural, a manutenção do contorno modal com a utilização de acordes de sétima sem trítonos, evitando assim possíveis implicações de acordes de sétima da dominante que poderiam induzir a escalas maiores, gera certo distanciamento das implicações tonais acarretando alguma ambiguidade harmônica e consequentes percepções politonais ou polimodais.

Diferente das Variations sur un Théma Original, em que Nepomuceno explicitava a bitonalidade, neste Trio ele se vale de uma "politonalidade ocasional", termo utilizado por Huguette Calmel para designar regiões baseadas em agregações harmônicas onde a sensação politonal não caracteriza tonalidades realmente independentes.

Segundo Calmel, em estudo sobre as obras de Arthur Honegger, este tipo de politonalidade é aquela onde "sem que a diligência das diferentes tonalidades seja realmente independente, encontra-se o emprego de acordes formados por superposições tonais cuja análise diferente seria artificial" (Calmel, 1978, p. 57).

Assim, o emprego de agregados modais de sétima sem trítonos opera uma transformação no sistema tonal, ${ }^{10}$ embora mantenha a direcionalidade das funções diatônicas com a possível pluralidade de "um espectro de centros tonais" (Noronha, 1998, p. 28).

Continuando nas considerações estruturais, observa-se que embora haja uma eventual ambiguidade harmônica acarretada pelo emprego da politonalidade ocasional, deve-se à manutenção das amarras ao suporte tonal a possibilidade da realização de uma obra imensa, de 1096 compassos e com 50 minutos de duração, aproximadamente. Em outros termos, Nepomuceno torna este suporte mais flexível ao empregar, ao lado do modalismo, cromatismo, progressões

\footnotetext{
${ }^{10}$ Segundo D. Milhaud, "a análise de um acorde é uma questão convencional e arbitrária e não há nenhuma razão, por exemplo, para considerar [o] acorde de [dó com] 9a maior como a superposição de um acorde de sol menor e dó maior [...]". "[...] I'analyse d'un accord est une question conventionnelle et arbitraire et il n'y a aucune raison par exemple pour ne pas considérer [cet] accord de $9^{\mathrm{e}}$ majeure comme la superposition d'un accord de sol mineur et d'ut majeur [...]." (Milhaud, 1923, p. 32).
} 
diminutas e escala de tons inteiros, sem quebrar uma tradição formal já sedimentada, produzindo assim uma grande estrutura.

Destarte, pode-se verificar que esta obra de grande dimensão apresenta a ordenação de seus movimentos de acordo com a crença de Vincent d'Indy, apregoado em seu Cours de Composition Musicale, isto é, Sonata, Lento, Moderado e Rápido, sendo esta uma prática formal ainda corrente, conforme testemunham o Trio op. 45 (1916) de Henrique Oswald, executado no mesmo recital de 31 de agosto de 1916, ou no Trio $n^{\circ} 1$ (1911) de Heitor Villa-Lobos.

Contudo, não eram mais novidade as modificações nas formas musicais resultantes do conteúdo empregado, devidas ao questionamento das técnicas de composição musical, como as explorações tímbricas ou harmônicas.

Mantendo-se o foco na forma cíclica, tais transformações podem ser diagnosticadas tanto no Quarteto de Cordas (1893) ou na Sonata para violoncelo e piano (1915), de Claude Debussy, quanto no Quarteto de Cordas $n^{\circ} 2$, op.10, em Fá sustenido menor (1907-08), de Arnold Schoenberg.

Enquanto em seu Quarteto Debussy se vale, além de um tema cíclico, de 62 uma identidade tímbrica como elemento recorrente e unificador de seus movimentos, em sua Sonata para violoncelo e piano, pelo emprego de um material subsidiário do primeiro movimento em seu movimento final, Debussy "subverte um dos princípios da organização cíclica: o reconhecimento do tema". ${ }^{11}$

Já Schoenberg apresentou uma alternativa inusitada como solução ao dilema enfrentado em seu Quarteto de Cordas $n^{\circ} 2$, obra de transição que, embora ainda tonal, já tomava ares atonais. Segundo seu compositor, tratava-se de seu retorno a uma obra cíclica, baseada em dois grupos de temas principais e alguns subsidiários. No entanto, o seu conteúdo harmônico, que abandonava a proteção do sistema tonal, exigia uma solução formal para viabilizar a realização de um quarteto. Logo, o emprego de um poema, do simbolista Stefan George, em seu terceiro e quarto movimentos, mostrou-se como uma alternativa possível para a sua concretização. Além disto, tendo o primeiro movimento um

\footnotetext{
${ }^{11}$ Sobre a utilização por Debussy da forma cíclica, ver Wheeldon (2005).
} 
desenvolvimento restrito e o segundo a sua omissão, coube ao seu terceiro movimento, estruturado como Tema e Variações e cujos motivos geradores são oriundos dos dois tempos anteriores, atuar como "seção de desenvolvimento do Quarteto", segundo Anton Webern (1883-1945). ${ }^{12}$ Desta maneira, além da introdução de texto em um Quarteto de Cordas, uma visão panorâmica conduz a idealizar uma obra de um único movimento com quatro subdivisões (seções $A$ e $B$, desenvolvimento, final).

Outro viés questionador da manutenção das grandes formas musicais, principalmente daquelas oriundas da tradição wagneriana e empregadas por Richard Strauss e Gustav Mahler, manifestou-se no cultivo das miniaturas. Diferentemente do esgotamento formal oriundo do emprego da técnica atonal, naturalmente geradora de miniaturas, a mesma tendência se manifestou em algumas obras onde o tonalismo ainda era fundamental. Tal é o caso das Sinfonias de Câmara (1917-1923) de Darius Milhaud, cuja primeira, Le Printemps, foi estreada no Brasil, em 22 de agosto de 1918, sob a batuta de Alberto Nepomuceno (Corrêa do Lago, 2005, p. 56).

Logo, a maneira que Nepomuceno emprega a modalidade, o cromatismo, as progressões de acordes diminutos ou as formações de tons inteiros não gerou a necessidades de afastamento da forma tradicional da música de câmara. Assim, a sua contribuição para o modernismo musical possivelmente se encontre mais em seu trabalho harmônico que formal ou instrumental.

Novamente, considerando os exemplos citados e tendo as críticas portenhas como pano de fundo, possivelmente este vínculo formal com a tradição seja um dos fatores responsáveis pelas ponderações sobre a falta de atualidade desta obra.

\footnotetext{
12 Sobre o Quarteto de Cordas $n^{\circ} 2$, op.10, de A. Schoenberg, ver: Samson (2002, p. 104113). Também como referência, a análise realizada pelo próprio compositor que consta no álbum Neue Wiener Schule - Schoenberg, Berg, Webern, Streichquartette. Hamburg: Deutsche Grammophon, n. 419.994-2, 1971, p. 42-57.
} 


\section{Considerações analíticas}

A análise do Trio mostra uma obra de extrema complexidade, apresentando o seu primeiro movimento na forma sonata cíclica com Introdução e Coda (Tabela 1).

Tabela 1 Resumo estrutural do primeiro movimento

\begin{tabular}{|c|c|c|c|c|c|c|c|c|c|}
\hline \multicolumn{10}{|c|}{$\frac{\text { o em Fá \# menor, para piano, violino e violoncelo (Alberto Nepomuceno) }}{1^{\circ} \text { movimento }}$} \\
\hline Introdução & \multicolumn{3}{|c|}{ Exposicão } & \multicolumn{2}{|c|}{ Desenvolvimento } & \multicolumn{3}{|c|}{ Reexposição } & Coda \\
\hline & $\begin{array}{l}1^{a} \text { Região } \\
\end{array}$ & Transição & $2^{\mathrm{a}}$ Região & Desenvolvimento & Transição & $1^{a^{a} \text { Região }}$ & Transição & $2^{\text {a Região }}$ & \\
\hline$\alpha \alpha^{\prime} \beta \alpha^{\prime \prime}$ & A & $\varphi$ & B1-B2-B1 & A-B2-B1 & $\varphi^{\prime}$ & $\mathrm{A}$ & $\varphi^{\prime \prime}$ & B1-B2-B1' & $\alpha$ \\
\hline
\end{tabular}

Por sua vez, cada seção subdivide-se em várias partes onde ao motivo cíclico associa-se um caráter dinâmico específico, singularizando um temapersonagem que, conforme d'Indy, é o elemento que permite a unificação cíclica dos diversos trechos da obra (d'Indy, 1909, p. 377). Assim, tem-se que o componente $\alpha$ e suas variantes estão associados ao Molto lento, enquanto o elemento $\beta$ ao Doppio movimento. Já o componente $A$, vincula-se ao Allegro energico e marcato, enquanto B1 está relacionado com o Meno mosso ou Meno mosso e calmo, respectivamente na exposição e na reexposição, da mesma forma que B2 ao Un poco più mosso e ao Agitato. Na seção de desenvolvimento, esta associação se confirma pela organização das regiões temáticas de acordo com suas afinidades de caráter. Em outras palavras, estando o desenvolvimento subdividido em 3 seções. Nepomuceno aproxima as figurações A (Allegro enérgico marcato) e B2 (Un poco più mosso), seguindo-se de B1 (Meno mosso). Resulta daí um primeiro bloco Enérgico come prima (AB2) seguido de outro Meno mosso e calmo (B1). Desta maneira, devido à inversão dos motivos cíclicos da segunda região temática, o caráter geral da exposição está mantido.

Em sua introdução Molto lento-Doppio movimento-Molto lento come prima, de forma ternária, $\left(\alpha-\alpha^{\prime}\right)-\beta-\alpha$ ", encontram-se os motivos melódicos cíclicos que posteriormente serão transformados e desenvolvidos (Exemplo3). 
Exemplo 3 Desenvolvimento motívico
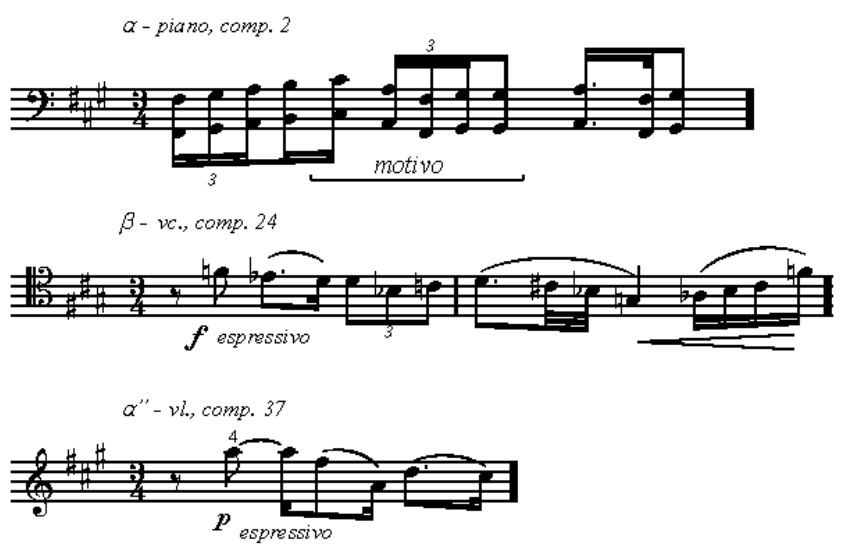

Em seu primeiro período $(\alpha)$, duas texturas distintas são apresentadas. A primeira, onde o tema principal encontra-se explícito, é uma monodia em oitavas graves que progride do quinto ao primeiro graus de Fá sustenido menor eólio, seguida por outra cordal arpejada que acompanha movimentações melódicas no violino e no violoncelo e conclui em uma cadência no quinto grau.

O período seguinte $\left(\alpha^{\prime}\right)$ parece afirmar a tonalidade com a repetição da textura monódica na tonalidade principal. Entretanto, por um movimento cromático, a textura cordal progride em Dó menor eólio antes de concluir em Ré maior, sexto grau do tom principal.

A próxima seção da introdução, $\beta$, apresenta o tema que será utilizado na primeira região da exposição (A), além de ser harmonicamente expandida no desenvolvimento. Subdividindo-se em 3 regiões, exibe progressões harmônicas mais complexas. Assim, $\beta 1$ progride de Sol menor eólio para Lá maior, (bemol ii7III), sendo que suas progressões se caracterizam pelo emprego de acordes de sétima sem trítonos. Em $\beta 2$, que repete a mesma textura, progride de Mi menor eólio à Dóg/7 sustenido maior, $\left(v i i 7-V^{9 / 7}\right)$, em uma progressão de dominantes individuais sem resolução. Já $\beta 3$ torna-se uma região enigmática e atonal, que progride cromaticamente enquanto as vozes das cordas são tratadas polifonicamente (Exemplo 4). 
Exemplo 4 Figuração de $\beta 3$, cromatismo atonal

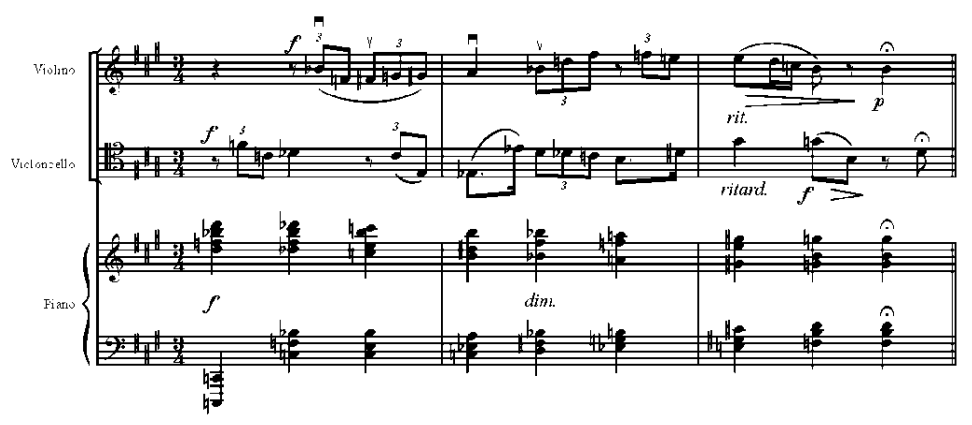

A introdução termina com a recapitulação da primeira seção, ( $\alpha$ "), agora com o predomínio de uma textura polifônica que contrapõem a monodia inicial de $\alpha$, no piano, com uma nova variação motívica no violino e no violoncelo. Sua conclusão se dá por um movimento cadencial dissimulado devido a ausência da sensível, o que reforça o seu caráter modal. Colabora ainda com este sentido cadencial a movimentação dos baixos, em uma relação v-i, em conjunto com uma rarefação de suas densidades e dinâmicas. Por fim, um extenso pedal de Fá sustenido, apoia uma harmonia oscilante no quinto grau, concluindo em Fá sustenido menor com a sexta agregada (Exemplo 5).

Exemplo 5 Cadência final da Introdução

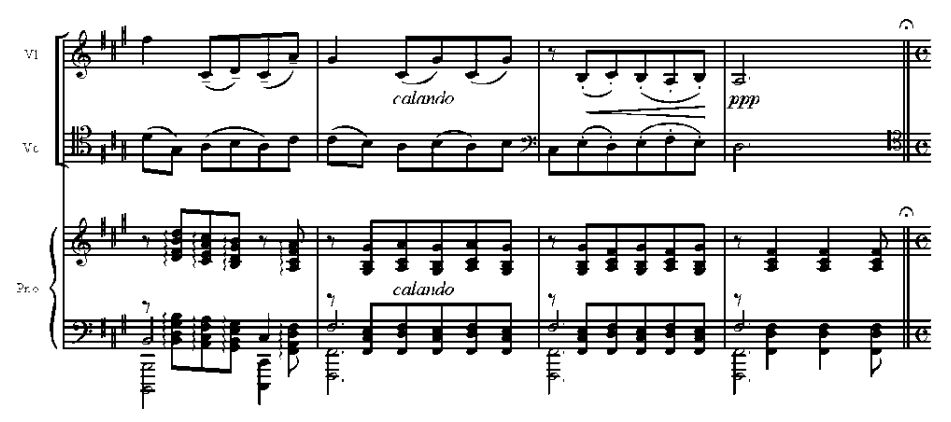

No compasso 51 tem início a exposição, com sua primeira região temática Allegro enérgico e marcato ( $\mathrm{A})$. Como já mencionado, a figuração temática da melodia já havia sido apresentada pelo violoncelo na seção $\beta$ da introdução, estando agora tratada por aumentação na tonalidade de Fá sustenido menor (Exemplo 6). 
Exemplo 6 Início da primeira região temática

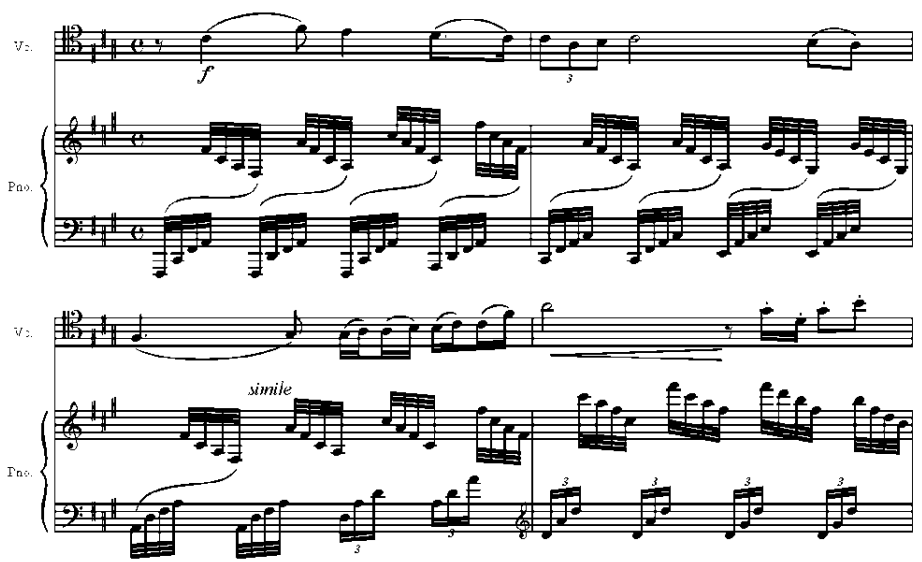

A resposta do violino, em Lá menor, inicia no compasso 62, mantendo, estruturalmente, uma relação de mediante cromática com a exposição anteriormente apresentada pelo violoncelo, concluindo em uma cadência suspensiva.

Estes dois terços iniciais desta primeira região temática caracterizam-se pelo emprego constante de acordes de sétima, preferencialmente sem trítonos, e pela falta de resolução em seus encadeamentos, invariavelmente apresentados sem a sensível.

O terço final desta seção, diferencia-se pela utilização de encadeamentos de acordes aumentados, sugerindo o emprego de tons inteiros (Exemplo 7). Conclui em uma cadência suspensiva diminuta, [(ii $\left.{ }^{\circ}\right)$ sustenido], encaminhando-se para a transição à segunda região temática.

Exemplo 7 Sugestão de tons inteiros

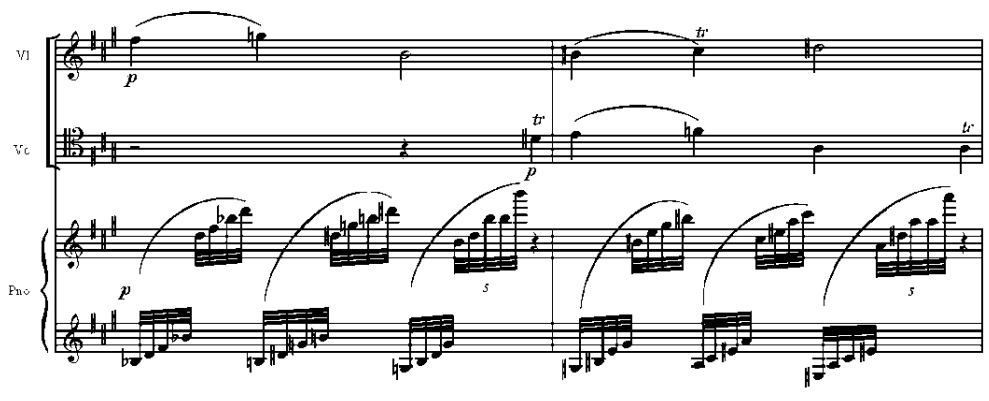


A transição à segunda região temática Animato $(\varphi)$ segue a figuração melódica do terço final da região A, extraída da melodia inicial do Trio, sendo esta figuração um dos elementos cíclicos mais importantes. Observa-se ainda uma maior proximidade $\operatorname{com} \alpha$, da introdução, devido a semelhança entre as texturas empregadas, apesar da fragmentação melódica. Harmonicamente, progride pelas tonalidades de Dó sustenido menor - Mi menor - Sol menor, sendo esta última prolongada sobre baixos cromáticos.

Nos compassos 105-144 principia a segunda região temática Meno mosso (B), que se divide em 3 subseções. A primeira, B1, que se desenvolve entre os compassos 105-112, inicia-se por uma aparente configuração polimodal e politonal, sugerida pela sobreposição de um pedal de Ré maior nas cordas a uma figuração temática em Si menor eólio no piano. Entretanto, a condução da voz interna do piano orienta a fixação de Ré maior como tonalidade básica, embora não haja cadências harmônicas que a defina.

Também aqui pode ser observado o tratamento de mais dois elementos cíclicos: o emprego de acordes arpejados e os trêmolos. O elemento arpejado já pode ser encontrado na introdução do Trio, remetendo a sonoridade da harpa 68 pela ambientação criada, bem como na intensificação da densidade do acompanhamento empregado na primeira região temática.

Esta seção, B1, caracteriza-se por uma expressão mais delicada e etérea, em contraste com a ebulição da primeira região temática (A). Tal expressão é obtida pela combinação de um conjunto de elementos, tais como o distanciamento entre os registros empregados, o andamento menos movido, a dinâmica pianíssimo e a linha ascendente de trêmolos intercalados por pausas (Exemplo 8).

Na subseção seguinte, B2, Un poço più mosso, compassos 113-128, os desenvolvimentos motívicos são relevantes e asseguram a unidade dos elementos melódicos. A melodia apresentada, primeiramente pelo violino, oculta um elemento linear ascendente, marcado com círculos na figura abaixo (Exemplo 9), e outro composto de um salto de oitava seguido da sua sétima, ou segunda se realizado o tratamento da inversão intervalar, marcado por um retângulo. Estes elementos estão presentes na figuração de parte considerável do acompanhamento do piano. 


\section{Exemplo 8 Transição e início da Segunda Região Temática}
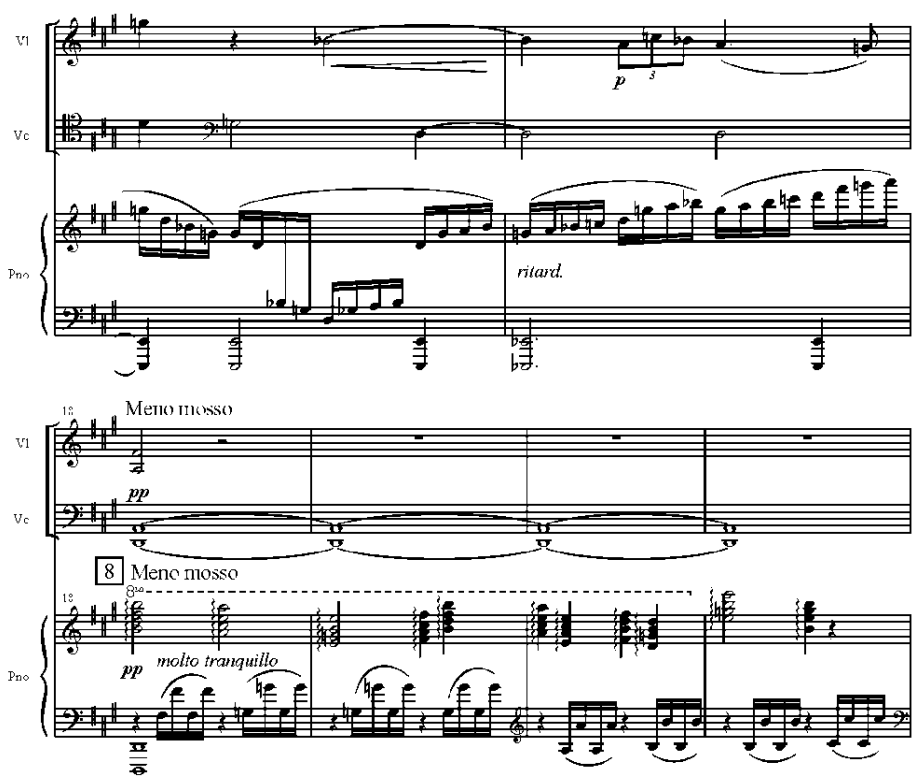

Exemplo 9 Desenvolvimento motívico

$\mathrm{V} 1$.

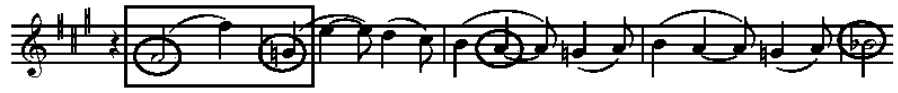

V1.

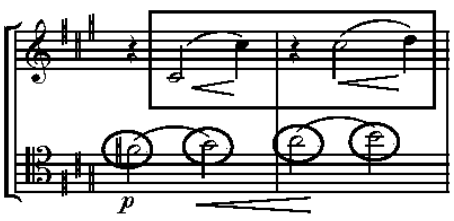

É possível ainda observar a unidade cíclica ao efetuar-se um paralelo entre as figurações melódicas de B2 e de A, conforme a figura abaixo (Exemplo 10).

Exemplo 10 Desenvolvimento motívico entre A e B2
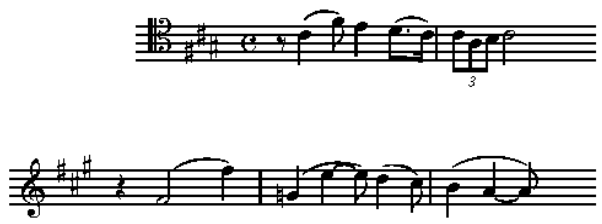
Desta maneira, observa-se que tanto o elemento motívico linear quanto os desvios de figuração entre os diversos elementos melódicos também se relacionam com um fragmento da frase inicial do Trio, importante componente para a forma cíclica da obra (Exemplo 11).

\section{Exemplo 11 Motivos temáticos}

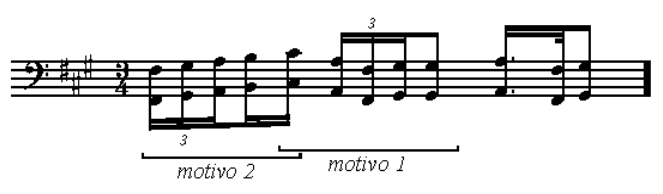

Harmonicamente é uma região menos complexa, onde as progressões cromáticas no baixo são o fio condutor. Desta maneira, avança de Si menor eólio para Si bemol maior e daí para Fá sustenido menor eólio. Conclui de forma plagal novamente em Si menor eólio.

Encerra-se a segunda região temática retornando ao Meno mosso, B1', sendo agora uma reexposição resumida de B1 em uma disposição distinta. Desta vez o pedal de Ré maior encontra-se no piano, enquanto a figuração melódica, em stretto, ambienta-se nas cordas, que concluem com um grande pedal de Ré maior que se prolonga por seis compassos. Interessante observar a sobreposição de dois pedais ao final: enquanto as cordas apresentam um ambíguo Fá sustenido em posição de quinta, o piano, por sua vez, mantém o pedal de Ré, também em posição de quinta.

Novamente os elementos cíclicos trêmolo e arpejo de duas oitavas são empregados no acompanhamento do piano com certa complexidade rítmica devido a utilização da proporção $8 \times 6$.

O desenvolvimento, compassos 145-202, mantém a estrutura ternária já empregada na introdução e segunda região temática, na forma A-B2-B1. Entretanto, a semelhança com a seção A da exposição restringe-se a sua figuração melódica. Desta vez, a textura está mais densa, já que polifônica imitativa entre as cordas, enquanto o seu ritmo harmônico é mais dinâmico, baseando-se na progressão harmônica da parte $\beta 1$ da introdução. 
Desta forma, a porção A do desenvolvimento segue uma inusitada progressão entre Sol menor e Dó menor ao efetuar um desvio por dominantes individuais, conforme ilustrado a seguir.

Sol menor: $\mathrm{i}^{7}-\mathrm{VI}-\mathrm{i}-\mathrm{III}^{7}-\mathrm{VI}^{7}-\mathrm{vii}$

$\downarrow$

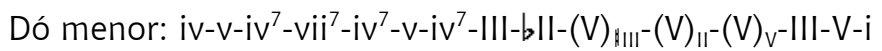

Segue uma nova exposição melódica de A, agora progredindo de Dó menor à Fá sustenido menor.

A seção B2, Exemplo 12, mantém a textura linear de A, embora mais densa em virtude dos amplos arpejos do piano. Sua densidade cromática, no entanto, cria uma região de complexa compreensão harmônica, já que realizada em progressões harmônicas remotamente relacionadas. Contudo, sua conclusão ocorre em uma cadência IV-I, em Mi maior, retomando B1 (Exemplo 12).

Encerrando a seção de desenvolvimento, retorna-se ao politonalismo ocasional e à regularidade formal de B1. No entanto, o vínculo com a parte anterior, B2, continua pela manutenção, no violoncelo, da sua figuração rítmica em ostinato.

Novamente o elemento de transição $\varphi$ é apresentado, transposto uma terça menor acima, reconduzindo à reexposição onde $\mathrm{A}$ é repetida literalmente. Uma terceira exibição de $\varphi$, extremamente condensada e disposta em relação de mediantes, conduz à segunda região temática, B.

Por sua vez, a reexposição de B segue a tradição da resolução dos conflitos harmônicos gerados no transcurso deste movimento. Destarte, mantendo a mesma estrutura regular, B1 encontra-se em Fá sustenido maior; B2 é reapresentada uma terça maior acima da sua realização na exposição; termina com a reexposição de B1. Conclui com um longo pedal de Fá sustenido maior.

Este primeiro movimento finaliza com uma Coda que resgata o temperamento grave do início da obra. O ciclo se fecha com a reapresentação do material $\alpha$ da introdução, encerrando-se por uma cadência plagal. 


\section{Exemplo 12 Desenvolvimento, seção B2}
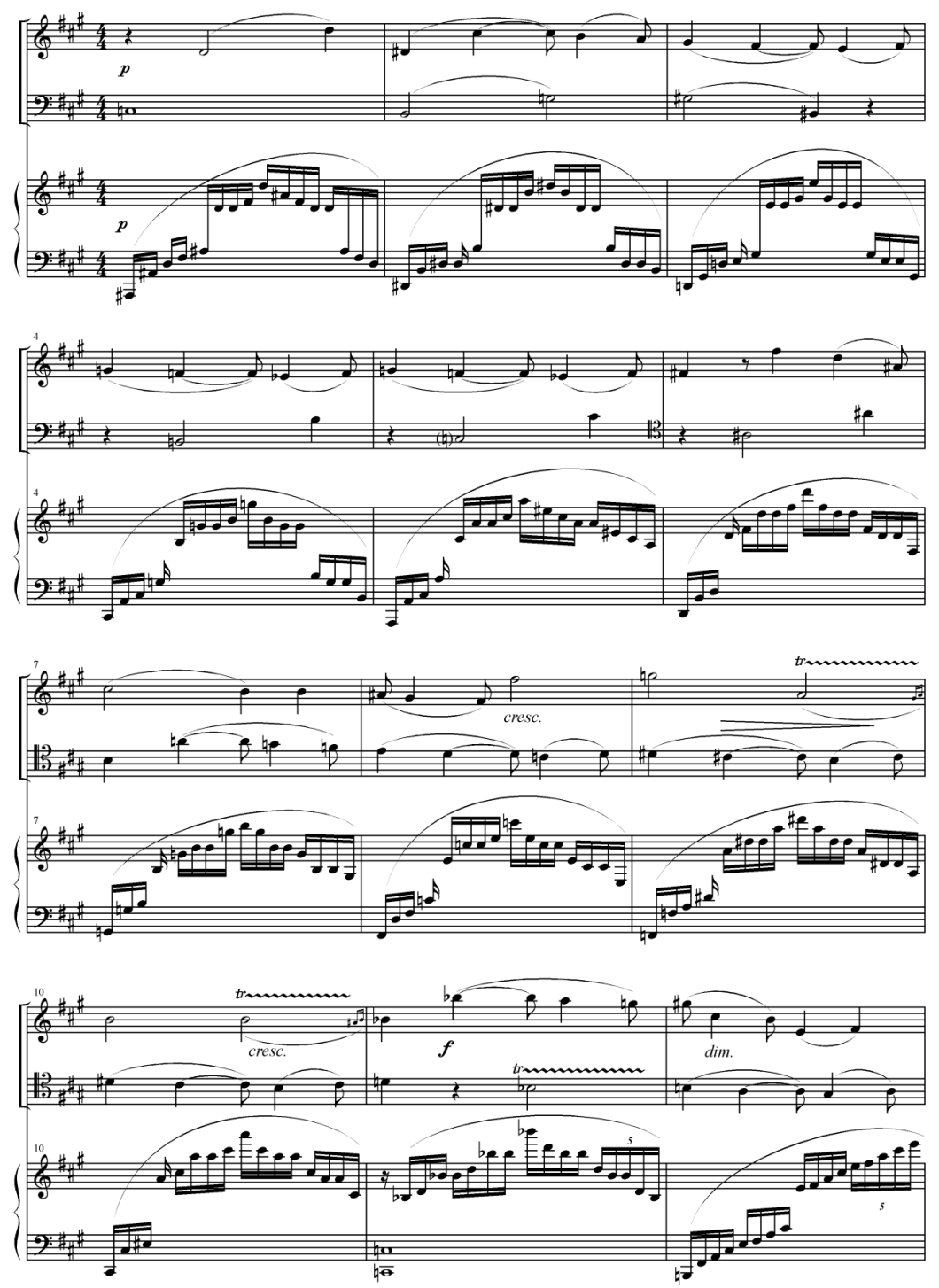

O segundo movimento, ao lado do primeiro, recebeu os mais positivos comentários de seus críticos. Fazendo-se uma composição entre eles, talvez melhor se perceba a índole deste Lentamente: "Particularmente expressivo" (La Argentina, 11/12/1919) e “atraente" (La Razón, 11/12/1919), o “comovente” (Messager, 16/9/1916) movimento lento transmite um "profundo sentimento" (Luiz de Castro, 1/9/1916) de “indiscutíveis belezas” (Tribuna Española, 11/12/1919). 
Pelo fato de não oferecer surpresas formais (Tabela 2), já que segue a forma da Sonate lente avec développement, conforme terminologia empregada por Vincent d'Indy (d'Indy, 1909, p. 301), deve-se ao seu conteúdo expressivo suscitar tais sentimentos.

Tabela 2 Resumo estrutural do segundo movimento

\begin{tabular}{|c|c|c|c|c|c|c|c|}
\hline \multicolumn{8}{|c|}{$\frac{\text { Trio em Fá \# menor, para piano, violino e violoncelo (Alberto Nepomuceno) }}{2^{\circ} \text { movimento }}$} \\
\hline \multicolumn{3}{|c|}{ Exposição } & Desenvolvimento & \multicolumn{3}{|c|}{ Reexposição } & Coda \\
\hline $1^{\mathrm{a}}$ Regiäo & Transiçẵo & $2^{\text {a Regiăo }}$ & & $1^{\mathrm{a}}$ Regiẫo & Transiçắo & $2^{\text {a Regiä́o }}$ & \\
\hline A & $\varphi$ & $B$ & A (fragmento) & A & $\varphi "$ & $B$ & A \\
\hline Si Maior & SiM-DónM-Ré\#M-Sol\#m & Sol \# Menor & Rérn-Fám-Fá7 & Si Maior & Sim-Solm-Fá\#-Sim & SiMenor & Si Maior \\
\hline
\end{tabular}

Possivelmente a sua maior proximidade com a tradição, já que estruturada em tonalidades diatonicamente relacionadas, o tenha tornado mais palatável. No entanto, mantém-se a predominância da densidade das progressões de harmonias de sétima sem trítono, o que Ihe dá uma cor característica.

Assim, harmonicamente este movimento progride em sua macroestrutura nas tonalidades vizinhas de seu tom principal. Em outras palavras, enquanto a seção A de sua exposição apresenta um novo material melódico em Si maior, após uma curta transição, B exibe uma variação do motivo cíclico $\alpha$ (Exemplo 13) em Sol sustenido menor eólio (deve-se lembrar que o elemento $\alpha$ é modal), seu relativo menor. Já em sua reexposição, as tonalidades/modalidades envolvidas são as homônimas Si maior e Si menor eólio.

Exemplo 13 Variação do motivo cíclico

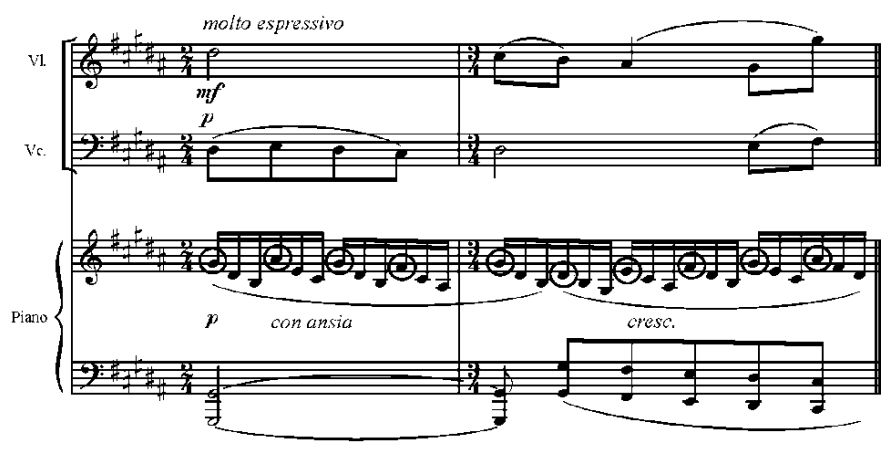


Além das relações harmônicas citadas, isto é, de uma organização tonal contrastando com outra modal, outros elementos definidores das regiões $A$ e $B$ são, respectivamente, a textura cordal frente à linear, além da agógica lentamente contraposta ao molto espressivo, con ansia.

Em seu curto desenvolvimento, construído sobre fragmento de A, observase o emprego de um cânone invertido entre as vozes das cordas, sob o qual o piano realiza um acompanhamento cordal em escala ascendente. Sua progressão harmônica, no entanto, encontra-se em relação de mediante cromática com a tonalidade básica de Si maior, substituindo-a como referência na seção. Desta maneira, encontra-se nesta seção uma progressão entre Ré menor e Fá Maior, ambas em relação diatônica de proximidade.

Duas particularidades ainda devem ser abordadas neste desenvolvimento. Após atingir a tonalidade de Fá maior, e antes de convertêlo em uma harmonia de sétima da dominante, ocorre um desvio harmônico para Lá bemol maior, uma pequena dissimulação que retorna repentinamente para a progressão $\mathrm{Mi}^{7}$ menor, Sol ${ }^{7}$ menor, Dó menor e, por fim, Fá ${ }^{7}$ maior, fechando em uma cadência suspensiva. A seguir, observa-se o abrupto retorno 74 a Si maior, início da reexposição.

Conclui em uma coda que recapitula a seção A. Interessante observar neste final a intenção expressiva por Nepomuceno ao empregar surdinas nas cordas em conjunto com a indicação Con racoglimento. Neste contexto, enquanto o violino apresenta uma variação rítmica da melodia e o violoncelo mantém um baixo de dominante, o piano realiza uma escala ascendente de pouco mais de duas oitavas, em dinâmica pianíssimo e com articulação ligada. Possivelmente aqui se possa inferir a antecipação da simbologia utilizada em Le Miracle de la Semence, que será abordada na próxima seção, na busca pelo infinito.

O terceiro movimento, na forma Scherzo-Trio, embora também não apresente novidades formais (Tabela 3), combina um elemento potencialmente desestabilizador, a escala hexatônica, com uma estrutura definitivamente dependente das relações diatônicas. Assim, deve-se aos modelos rítmicos empregados a estabilização da estrutura como um todo. 
Tabela 3 Resumo estrutural do terceiro movimento

Trio em Fá \# menor, para piano, violino e violoncelo (Alberto Nepomuceno)
\begin{tabular}{|c|c|c|c|c|c|c|c|c|}
\hline \multicolumn{7}{|c|}{$\mathbf{3}^{\circ}$ movimento } \\
\hline \multicolumn{7}{|c|}{ Scherzo } & Trio & \multicolumn{4}{c|}{ Scherzo } \\
\hline A & Transição & B & A & C & Transição & A & B & A \\
\hline aa' & $\varphi$ & b-b'-b & a & c & $\varphi$ & a & b-b'-b & a \\
\hline Sim & & SiM-MibM-SiM & Sim-RéM & LáM & & Sim & Fá\#M-SibM-Fá\#M & Sim-RéM \\
\hline
\end{tabular}

Sua originalidade rítmica, que já havia sido diagnosticada tanto por André Messager em seu concerto de estreia, em 1916, quanto na Audición de Obras de Compositores Brasileños, três anos após (La Prensa, 11/12/1919), origina-se da variação rítmica de um dos motivos cíclicos extraídos da região $\alpha$ da introdução do Trio (Exemplo 14), fundamental na seção A do Scherzo.

Exemplo 14 Tema cíclico e sua variação rítmica

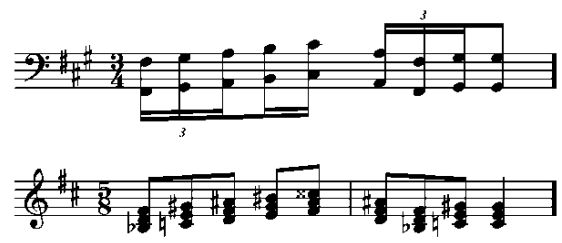

No entanto, seus encadeamentos harmônicos também guardam sonoridades e movimentos insólitos, como se observa na sua tonalidade inicial, Si menor, camuflada por figuração de tons inteiros, ou nas relações não diatônicas apresentadas na seção B do Scherzo.

Estruturalmente, a exposição da primeira seção fixa a tonalidade (a Exemplo 15), enquanto sua repetição (a') a conduz à dominante, preparando a entrada de $B$.

Em sua seção $B$, uma nova figuração melódica torna sua movimentação mais fluida, enquanto o piano mantém um ostinato rítmico extraído do modelo de seu primeiro compasso. Harmonicamente realiza o arco Si maior - Mi bemol maior - Si maior. Segue-se a reexposição de a, onde se manifesta uma ambiguidade harmônica: embora esta seção esteja em Si maior, seu final, após um compasso de silêncio, pontua a movimentação V-I em Ré maior. 
Exemplo 15 Início do Scherzo - exposição a
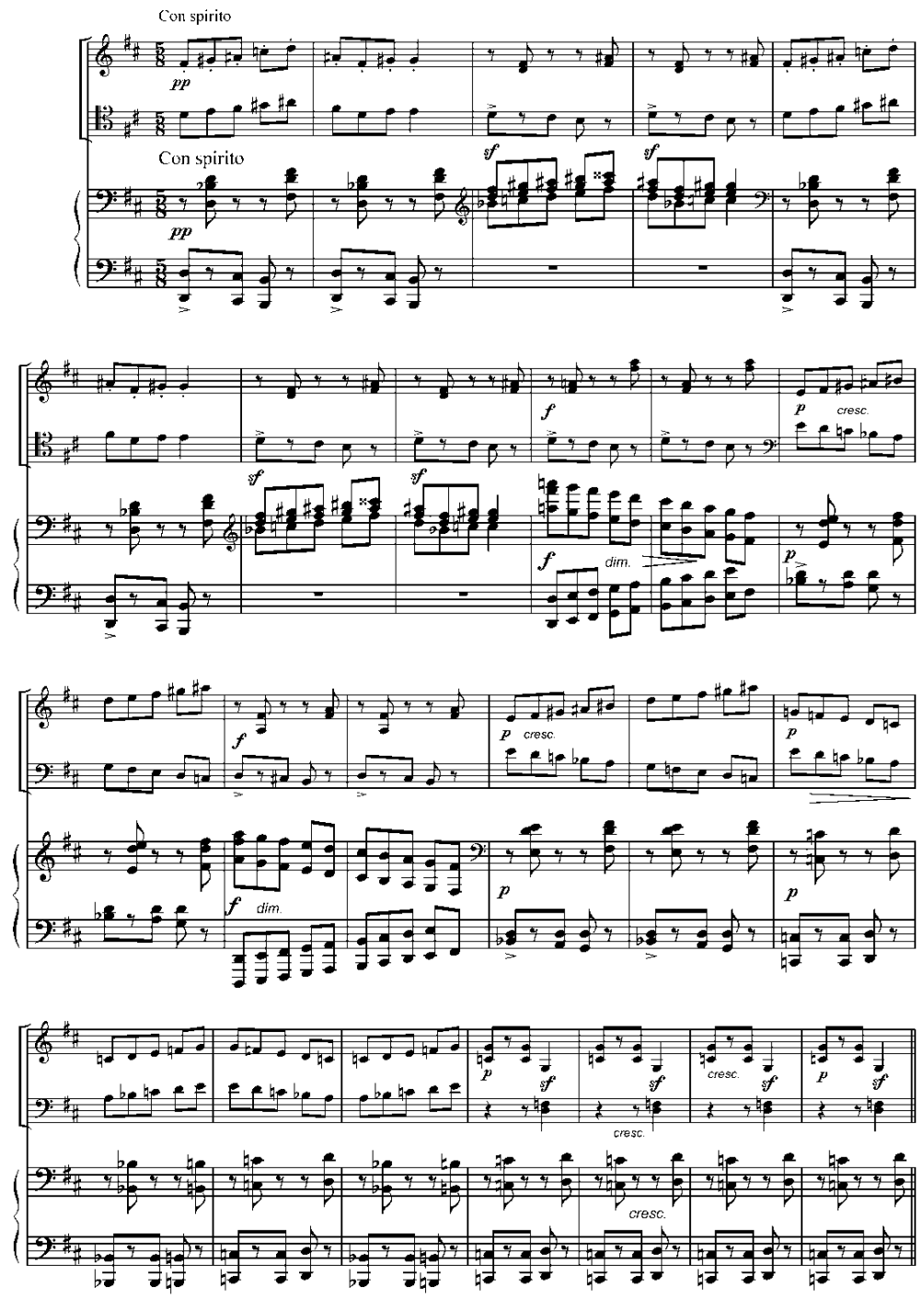

O Trio, um Quasi andante em Lá maior, é mais gracioso e expressivo que o Scherzo. Nele as relações harmônicas são preferencialmente diatônicas e em sua figuração melódica encontra-se uma lembrança da primeira região temática da exposição do segundo movimento (Exemplo 16). 
Exemplo 16 Elemento cíclico do $2^{\circ}$ movimento encontrado no Trio

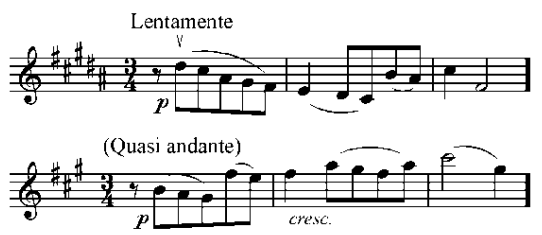

Estruturalmente, pode-se definir uma forma ternária contínua, não seccional, definida por suas texturas, tendo, perto de seu final, um enxerto "a tempo giocoso", em tons inteiros. Em sua transição de retorno ao Scherzo, apoiado novamente em um ritmo ostinato, encontra-se uma raridade na técnica composicional de Nepomuceno: uma passagem polimétrica de 3/4 contra 5/8 (Exemplo 17).

Exemplo 17 Trecho polimétrico na transição do Trio à reapresentação do Scherzo

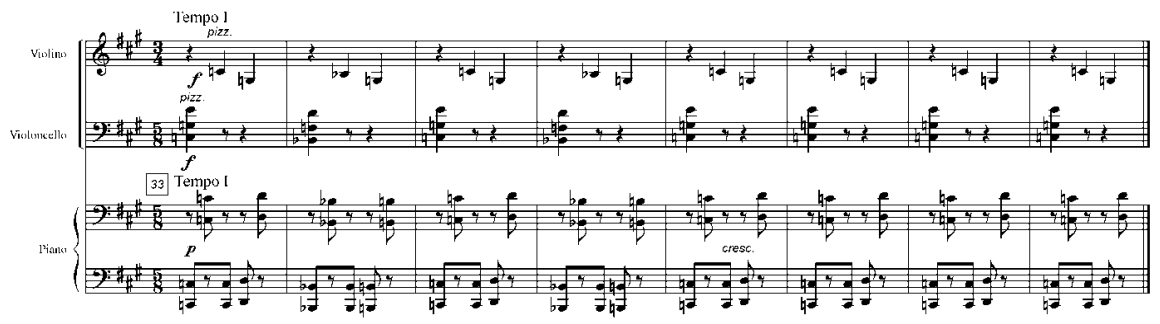

Segue-se a reexposição quase literal do Scherzo, diferenciando-se somente na seção B que, ao progredir no arco Fá sustenido maior -Si bemol maior - Fá sustenido maior, prioriza a região de dominante da tonalidade principal, Si menor, embora, novamente, conclua em Ré maior.

Por fim, seu quarto movimento volta à densidade e complexidade encontrada no movimento inicial da obra. Tal como nas partes anteriores, vale-se de um modelo da tradição, a forma sonata, para que seu conteúdo seja comunicado. Pode-se considerar que, em virtude de suas progressões entre harmonias remotas e de seu denso cromatismo, a utilização desta estrutura musical atue como âncora para a realização de algo inteligível. Isto pode ser 
inferido pelo fato de que, apesar dessas progressões, suas principais seções procuram se manter próximas das concepções de tensão e resolução que estruturam essas formas. Seu resumo estrutural pode auxiliar na compreensão das relações das várias seções deste movimento (Tabela 4).

Tabela 4 Resumo estrutural do quarto movimento

\begin{tabular}{|c|c|c|c|}
\hline \multicolumn{4}{|c|}{$\begin{array}{l}\text { Trio em Fá \# m enor, para piano, violino e violoncelo (Alberto Nepomuceno) } \\
4^{\circ} \text { movimento }\end{array}$} \\
\hline \multicolumn{4}{|c|}{ Exposição } \\
\hline Introduçẫo & $1^{\text {a Regiẫo }}$ & Transição & $2^{\text {a Regiẫo }}$ \\
\hline$\left(\alpha \alpha^{\prime \prime}\right)$ & $\mathrm{A}$ & $\varphi$ & $\mathrm{B}$ \\
\hline Fá\#m & Fá\#m-Ebm-Cm-Abm-V7 & Rém & RéM/SiM-DóM-Dóm/RéM \\
\hline \multicolumn{4}{|c|}{ Desenvolvimento } \\
\hline & A & $\mathrm{B}$ & $\mathrm{A} / \varphi$ \\
\hline \multicolumn{2}{|c|}{ Dóm-Mibm-FáM } & SibM-RéM/Dó\#m-Rém & Fá\#m \\
\hline \multicolumn{4}{|c|}{ Reexposição } \\
\hline Introduçẫo & $1^{\text {a Regiẫo }}$ & Transiçã̃o & $2^{\text {a Regiẫo }}$ \\
\hline$\left(\alpha \alpha^{\prime \prime}\right)$ & $\mathrm{A}$ & $\varphi$ & $\mathrm{B}$ \\
\hline Fá\#m & Fá\#m-Ebm-Cm-Abm-V7 & Fá\#M & Fá\#伊ibM-MiM-Mim/Fá\#M \\
\hline \multicolumn{4}{|c|}{ Coda } \\
\hline \multicolumn{4}{|c|}{ Frase Matriz } \\
\hline \multicolumn{4}{|c|}{ Fá\#M } \\
\hline
\end{tabular}

Como se viu, Messager, em sua consideração sobre este Trio, constatou que este último tempo resumia e comentava a obra inteira. No entanto, sua 78 intenção não se restringe aí, já que também se mostra como um componente complementar ao restante da composição.

Tais diagnósticos podem ser confirmados na introdução encontrada nas seções de Exposição e Reexposição, bem como em sua Coda, tanto quanto nos motivos geradores das $1^{\mathrm{a}}$ e $2^{\mathrm{a}}$ regiões melódicas.

Assim, no início deste último movimento encontra-se o resumo da introdução do primeiro tempo do Trio, isto é, após fragmento do motivo inicial aumentado, excerto de $\alpha$, cuja fermata a seguir contém a expressão de seu complemento, segue-se um recitativo contrapontístico a duas vozes nas cordas que nada mais é do que uma lembrança da mesma figuração melódica executada na reexposição daquela seção introdutória, $\alpha$ " (Exemplo 18). 
Exemplo 18 Início do $4^{\circ}$ movimento: Condensação de $\alpha$ e $\alpha$ " da introdução do $1^{\circ}$ movimento

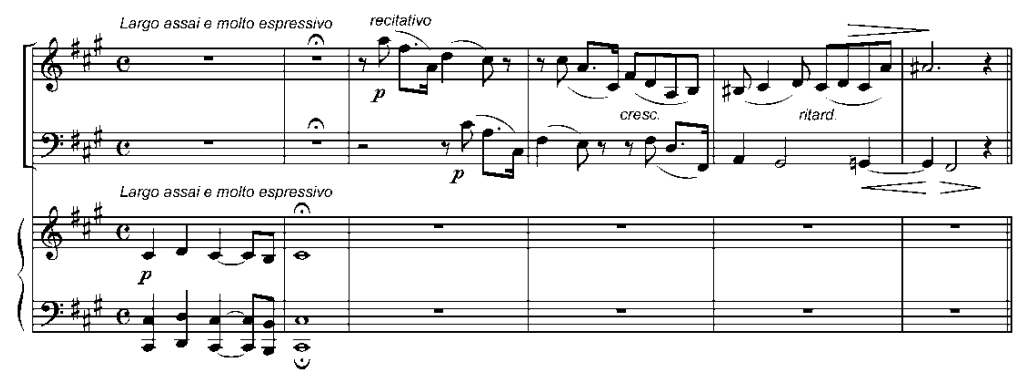

Em sua continuação, novamente o excerto de $\alpha$ é encontrado, agora em tratamento sequencial uma segunda maior abaixo, apresentando como consequente o restante da melodia de $\alpha$ ".

Importante observar o desenvolvimento motívico realizado por Nepomuceno no elemento melódico realizado pelas cordas. Como se mostra no Exemplo 19, a figuração de $\alpha$ (1) pode ser considerada a matriz de $\alpha$ " (2), da figuração 3 , seu complemento nesta introdução, bem como do elemento melódico da seção B (4) deste movimento.

Exemplo 19 Desenvolvimento motívico: primeiro grupo
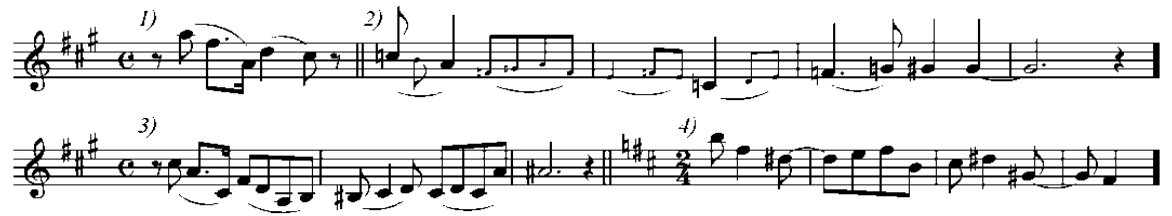

Ainda deve-se levar em consideração a importância cíclica assumida pelo componente $\alpha$ ao transformar-se no mote das seções que molduram a seção $B$, em Ré maior e, posteriormente, em Fá sustenido maior.

Já em sua Coda, o resumo de sua introdução dá lugar a expressão integral da frase geradora da obra, que reaparece em um Largo maestoso tratada por aumentação, onde a modalidade inicial cede à tonalidade maior.

Seu aspecto complementar aos demais movimentos deve-se ao motivo gerador do elemento melódico da seção A, utilizado pela primeira vez na obra. 
Interessante observar as fragmentações da frase geradora do primeiro movimento e de suas partições como motivos cíclicos para o restante da obra (Exemplo 20).

Exemplo 20 Partição motívica entre os movimentos do Trio

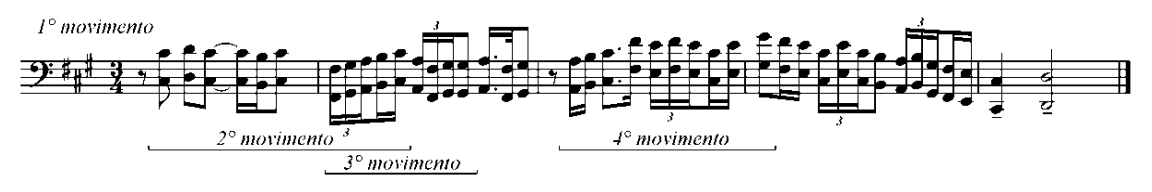

Assim, o trecho inicial da segunda metade desta frase é fragmentado e variado cromaticamente em retrogradação, gerando aí o motivo melódico da primeira seção temática (Exemplo 21).

Exemplo 21 Desenvolvimento motívico para a seção A

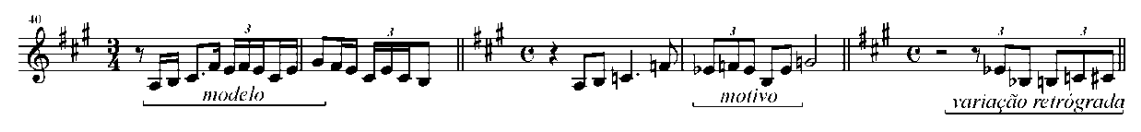

Retornando à recepção pública do Trio, também uma série de diagnósticos negativos the foi atribuído. Em sua execução portenha, este movimento foi considerado confuso (La Vanguardia, 12/12/1919), responsável pela falta de unidade (Tribuna Española, 11/12/1919) e consequente enfraquecimento da obra.

Parcialmente se encontra a justificativa para isto por ser a parte mais hermética do Trio, em virtude de seu denso cromatismo, gerador de um constante senso de falta de centro tonal, além de efetivamente empregar encadeamentos harmônicos de remotíssima relação diatônica.

Assim, após a sua introdução e tendo como motivo a variação retrógrada, a seção A inicia com um longo trecho cromático que beira ao atonalismo (Exemplo 22), resultante da sobreposição polifônica entre o piano e as cordas, antes de chegar ao porto seguro de Fá sustenido menor, progredindo daí para $\mathrm{Mi}$ bemol menor, Dó menor e Lá bemol menor. Segue-se uma sequência cromática de quintas aumentadas e de acordes de sétima da dominante. Logo, tem-se 
que o cromatismo é o elo condutor desta seção que conduz a uma breve transição para a seção B.

Exemplo 22 Início cromático da seção A

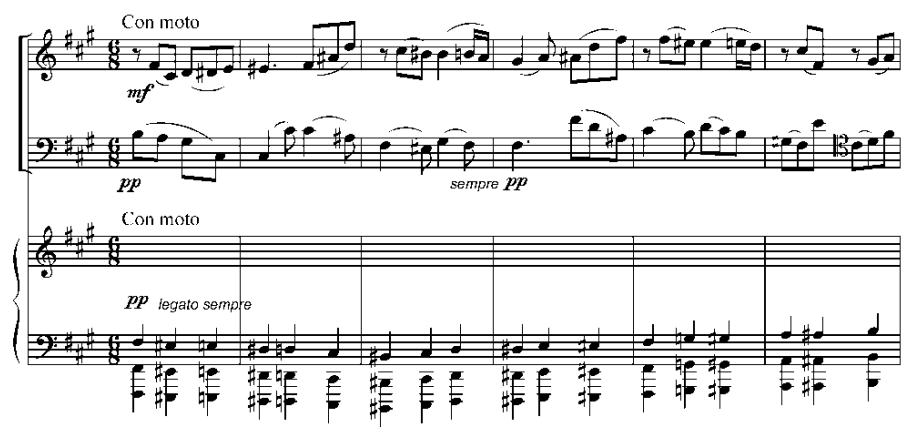

A segunda região, B, em forma ternária, remete-se a mesma estrutura condensada do início do movimento, embora muito mais ampliada. O curto fragmento monódico, em Ré maior, encontra-se expandido por repetição e tratamento sequencial, emoldurando a seção intermediária. Também aqui pode ser constatado o emprego da figuração em oitavas, configurando outro elemento cíclico já que frequente em todos os movimentos do Trio (Exemplo 23).

Exemplo 23 Início da seção A, baseada em fragmento do motivo monódico

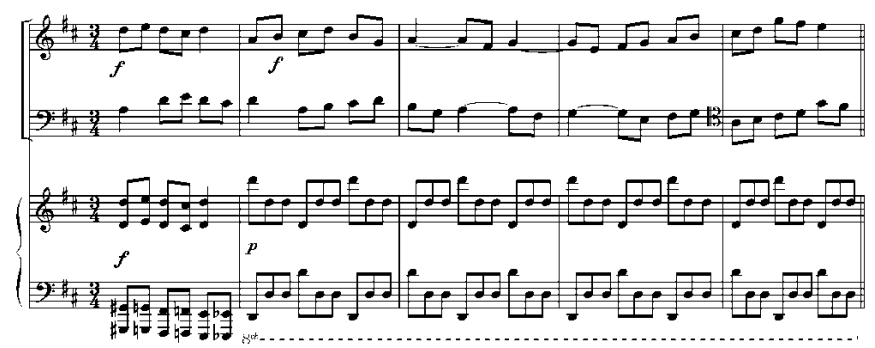

Por sua vez, a seção intermediária tem a sua melodia construída a partir da resposta das cordas ao fragmento monódico do início do movimento, conforme tratado anteriormente e ilustrado no Exemplo 19. Também subdividida em três partes, definidas harmonicamente pela progressão Si maior - Dó maior Dó menor (Exemplo 24), verifica-se que enquanto as duas primeiras, sequenciais, 
concluem em cadência suspensiva, a última, uma variação de seu fragmento descendente, conduz ao retorno da "seção moldura", em Ré maior. Ao final, o rebaixamento para Ré bemol maior encaminha a volta do cromatismo na seção de Desenvolvimento.

Exemplo 24 Parte intermediária da seção B

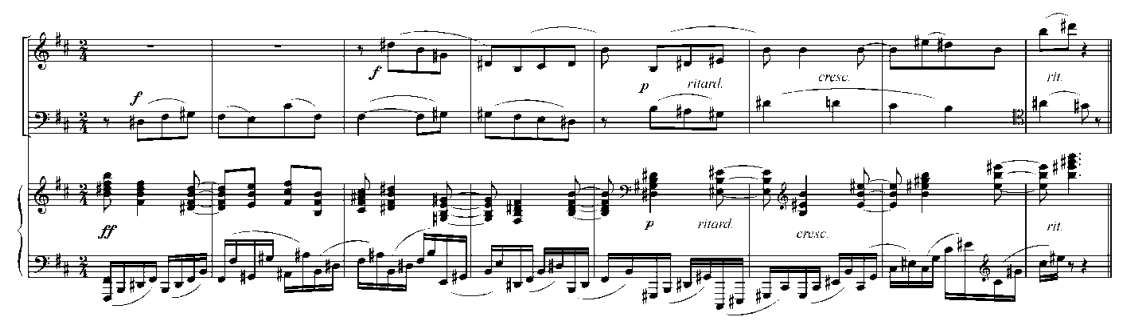

Em sua seção de Desenvolvimento, o gesto romântico se manifesta no lirismo empregado, resultante também do predomínio de acompanhamento arpejado no piano. Novamente Nepomuceno se vale da tripartição, entretanto supervalorizando a região $B$.

Na primeira parte, que tem como fundamento motívico a figuração do

82 trecho A da Exposição, há o retorno do cromatismo à cena, o que reflete as progressões harmônicas empregadas. Desta forma, e devido à textura polifônica, notas não diatônicas são agregadas aos acordes ao mesmo tempo em que há a predominância de harmonias de sétima, diminutas ou sequências de acordes por trítonos. A grande densidade do trecho deve-se também a evasão das suas resoluções tonais, o que torna mais turva as suas identificações (Exemplo 25), que aqui progridem entre Dó menor, Mi bemol menor e Fá maior.

Particular interesse se encontra em dois encadeamentos que mantém a tensão do movimento. O primeiro revela uma resolução inusitada, na passagem entre os compassos 4 e 5 do Exemplo 25, onde um acorde diminuto do segundo grau, sobre pedal de dominante, evita a resolução tradicional no quinto grau ao ser conduzido a este rebaixado, agrupado como sétima da dominante (ii $7 / 5^{\circ}$ bemol V7). O seguinte, entre os compassos 6-8, pode ser observado na movimentação que a formação harmônica por trítonos realiza, onde encontra a sua resolução em um acorde de sétima da dominante ( $M i$ bemol 7 maior) 
que, entretanto, evita a resolução ao encadear-se em uma harmonia de nona (Dó9/7 maior).

Os dois terços restantes deste Desenvolvimento se detém em elementos oriundos da região $\mathrm{B}$ da exposição. Contudo, o inesperado não se restringe às suas progressões harmônicas, que se mantém no mesmo viés até agora empregado dos encadeamentos não diatônicos. Neste início, Nepomuceno eleva um tema subsidiário, que atuava como contraponto de B em sua Exposição, à melodia principal (Exemplo 26).

Exemplo 25 Início do trecho A do desenvolvimento

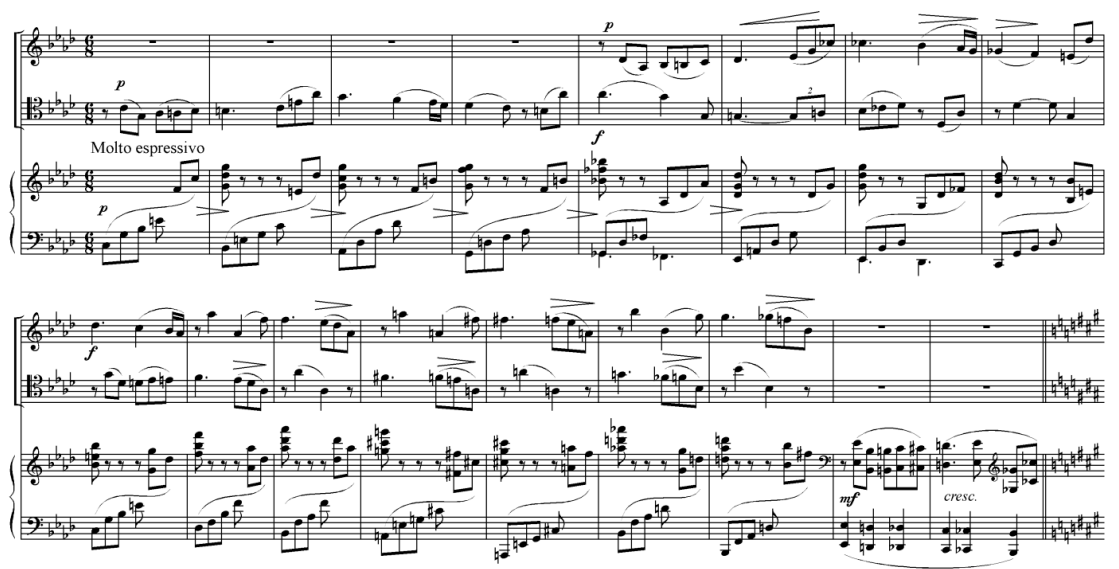

Exemplo 26 Início do trecho B do desenvolvimento

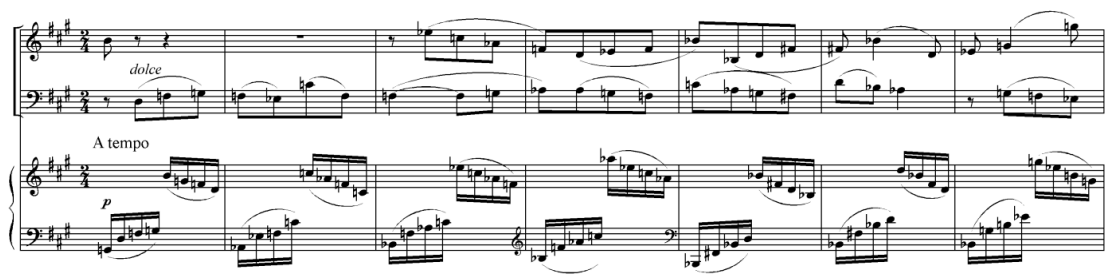

Não obstante, embora ainda seja possível pelas figurações melódicas das cordas definir as tonalidades das suas regiões, Si bemol maior e Ré maior, a harmonização realizada não as torna evidentes, já que parecem orientar para terrenos indefinidos, isto é, a expectativa melódica parece divergir da harmônica. A solução desta aparente incompatibilidade realiza-se pelo elemento cromático 
que surge como condutor da movimentação expressiva. Logo, após uma sequência cromática de acordes aumentados, entra-se no último terço do Desenvolvimento.

Em seu último terço, a melodia principal de B é reapresentada. Todavia, desta vez o piano a realiza solo, transposta uma segunda maior acima e nas tonalidades menores de Dó sustenido e Ré. Intermediando estas exibições, encontra-se um recitativo de fragmento da melodia subsidiária anteriormente utilizada. Encerra com uma cadência suspensiva no segundo grau da tonalidade de Fá sustenido menor, (ii $\left.{ }^{\circ} 7\right)$ i.

A condução à Reexposição se dá pelo mesmo elemento melódico das demais transições deste quarto movimento, aparentado ao fragmento monódico do início, já na tonalidade principal da obra. Harmonicamente, trata-se de uma cadência suspensiva sobre um acorde de sétima diminuta.

Na seção de Reexposição, Nepomuceno repete literalmente o material empregado na introdução e na $1^{\text {a }}$ região temática da exposição. A alteração, de acordo com a expectativa da forma sonata, se dá pelo resgate da $2^{\text {a }}$ região temática das tonalidades remotas em que se aventurava na Exposição para a tonalidade principal do Trio, Fá sustenido. Assim, o material empregado na região

84 B encontra-se agora transposto uma terça maior acima e em seu modo maior, onde estabelece a progressão harmônica Fá sustenido maior/Mi bemol maior-Mi maior-Mi menor/Fá sustenido maior.

Como Coda, a frase inicial do Trio, em variação rítmica faz o fechamento Largo maestoso em Fá sustenido maior. Desta vez, o caráter grandioso é obtido pelo uníssono do tutti em fortíssimo.

Assim, após esta análise, observam-se como elementos básicos na construção deste Trio o emprego de relações de mediantes cromáticas costuradas por cromatismos que assumem funções estruturais já que substituem os padrões cadenciais convencionais.

No entanto, considerando-se que esta técnica não era uma exceção, pois já encontrada em alguns Lieder de Hugo Wolf, deve ser observado que se tratava de uma importante conquista da técnica musical do final do século XIX, embora tivesse como ponto de partida as últimas obras de Beethoven. 
Conforme demonstrado por Deborah Stein em Hugo Wolf's Lieder and the Extensions of Tonality (Stein, 1985) o emprego de relações de mediantes cromáticas carrega intrinsicamente ambiguidades funcionais que podem ocasionar uma organização tonal muito mais complexa ou mesmo levar ao rompimento das relações de tonalidade fixadas pela tradição.

Neste Trio, contudo, Alberto Nepomuceno não se restringe à utilização de uma cadeia de mediantes estruturalmente dispostas, agregando um outro elemento que não só será responsável pelo colorido da obra, mas que também reforçará as ambiguidades tonais. Trata-se do modalismo que, invariavelmente harmonizado por acordes de sétima sem trítonos, acarreta a percepção de uma politonalidade ocasional. Importante observar que esta qualidade de acorde, por não possuir a nota atrativa que o transfiguraria em uma dominante, reforça o seu caráter modal.

Ainda deve ser mencionada a utilização da escala hexatônica, sinônimo de Debussy, como elemento estruturante e colorístico que, em conjunto com progressões aumentadas e diminutas sem resolução concorrem para o turvamento de sua compreensão harmônica.

A solução para a combinação destes elementos de expansão tonal, que causam distanciamento da tradição romântica e abrem caminhos para uma nova expressão, manifesta-se em uma forma de compensação através do emprego de padrões motívicos rítmicos e melódicos e por algum tipo de simetria formal. (Stein, 1985, p. 221). Assim, Nepomuceno apresenta uma forma cíclica extremamente simétrica em cada um de seus movimentos.

Destarte, Nepomuceno apresenta uma obra eclética, cujo cromatismo e densidade aproximam-se da expressão da música germânica enquanto parte de seu colorido modal e hexatônico o colocam na direção da música francesa. Contudo, pela maior ênfase naquela, é possível entender o porquê para o crítico da Revista de la Asociación Wagneriana de Buenos Aires este Trio seria a obra de menos influência francesa daquele programa de música brasileira.

Logo, mesmo que este Trio em Fá sustenido menor não seja de fato a primeira obra de câmara de Nepomuceno, como pressupunha Messager, pois já havia composto os Quartetos de Cordas em finais do século XIX, fica patente a sua 
importância no conjunto da sua produção artística e para a moderna música de câmara brasileira, tal como expressou Henrique Oswald na crítica de Luiz de Castro para $A$ Noite, em setembro de 1916.

Não hesito em afirmá-lo, porque essa é opinião de outros mais competentes do que eu, como Henrique Oswald, que não hesitou em dizer, com a mais absoluta sinceridade, que não conhece na moderna literatura de trio nenhuma obra que the seja superior. (A Noite, 1/9/1916)

Tal diagnóstico é compartilhado por musicólogos que consideram ser esta obra uma das mais importantes de Alberto Nepomuceno. Almeida (1942, p. 433) refere-se ao Trio como "uma das suas melhores peças de música de câmara"; Azevedo (1956) o considera uma das composições mais importantes nos últimos anos do compositor; Neves (1977, p. 22) o julga de grande importância. Entretanto, e após a análise realizada, torna-se intrigante o fato de ela somente ser citada de passagem nas biografias do compositor.

\section{Referências}

ALMEIDA, Renato. História da Música Brasileira. 2. ed. Rio de Janeiro: Briguiet, 1942. ANGLÉS, H., Pena, J (org.). Diccionario de la Música Labor. Barcelona: Editorial Labor, 1954.

AZEVEDO, Luiz Heitor Corrêa de. 150 anos de música no Brasil. Rio de Janeiro: José Olympio, 1956.

CALMEL, Huguette. Quelques aspects de la polytonalité dans l'œuvre d'Arthur Honegger. L'Education Musicale. v. 35, nov., p. 57-61, 1978.

CORREAA do LAGO, Manoel Aranha. O Círculo Veloso-Guerra e Darius Milhaud no Brasil: Modernismo musical no Rio de Janeiro antes da Semana. Tese (Doutorado em Música). Programa de Pós-Graduação em Música do Centro de Letras e Artes, Universidade Federal do Estado do Rio de Janeiro (UNIRIO), 2005.

DAVIDIAN, Teresa. Debussy, d'Indy and the Société Nationale. Journal of Musicological Research. v. 11, p. 285-301, 1991.

D'INDY, Vincent. Cours de Composition Musicale, tomo 2, parte 1. Paris: Durand, 1909. DUCHESNEAU, Michel. L'Avant-garde musicale et ses sociétés à Paris de 1871 à 1939. Liège: Mardaga, 1997. 
MILHAUD, Claude. Polytonalité et Atonalité. Revue Musicale. v. IV, n. 4, fev. 1923, p. 29-44

NEVES, José Maria. Música Contemporânea Brasileira. São Paulo: Ricordi Brasileira, 1977.

NORONHA, Lina Maria Ribeiro de. Politonalidade: discurso de reação e transformação. São Paulo: Annablume, 1998.

SCHOENBERG, Arnold. Neue Wiener Schule - Schoenberg, Berg, Webern, Streichquartette. Hamburg: Deutsche Grammophon, n419.994-2, 1971. p. 42-57.

SAMSON, Jim. Samson, Jim. Music in Transition: a study of tonal expansion and atonality, 1900-1920. London: Oxford University Press, 2002.

STEIN, Deborah. Hugo Wolf's Lieder and the Extensions of Tonality. Ann Arbor: UMI Research Press, 1985.

WHEELDON, Marianne. Debussy and La Sonate cyclique. The Journal of Musicology. v. 22, Issue 4, p. 644-679, 2005.

\section{Periódicos}

A Noite, Rio de Janeiro, 1/set./1916.

Jornal do Commercio, Rio de Janeiro, 16/set./1916, 28/mai./1917.

La Argentina, Buenos Aires, 11/dez./1919.

La Epoca, Buenos Aires, 11/dez./1919.

La Nación, Buenos Aires, 12/dez./1919.

La Prensa, Buenos Aires, 11/dez./1919.

La Razón, Buenos Aires, 11/12/1919.

La Unión, Buenos Aires, 11/dez./1919.

La Vanguardia, Buenos Aires, 12/dez./1919.

Revista de la Asociación Wagneriana de Buenos Aires, dez./1919.

Tribuna Española, Buenos Aires, 11/dez./1919.

E-mail: guilherme_goldberg@hotmail.com

Artigo recebido e aprovado em 18 de outubro de 2010 